\title{
Morphometric Analysis of Karadya Micro Watershed: A Case Study of Mandya District
}

\author{
Ningaraju Holalu Javarayigowda ${ }^{1}$, Ganesh Kumar Shivamogga Basavaraju², \\ Surendra Halasuru Jayaram, * \\ ${ }^{1}$ Department of Civil Engineering, People's Education Society College of Engineering, Mandya, India \\ ${ }^{2}$ Department of Civil Engineering, Sri Dharmasthala Manjunatheshwara Institute of Technology, Ujire, India \\ ${ }^{3}$ Department of Civil Engineering, ATRIA Institute of Technology, Bangalore, India
}

\section{Email address:}

hjnraju@gmail.com(N. H. Javarayigowda), ganeshkumar.sb@gmail.com(G. K. S. Basavaraju), surendra@atria.edu(S. H. Jayaram)

${ }^{*}$ Corresponding author

\section{To cite this article:}

Ningaraju Holalu Javarayigowda, Ganesh Kumar Shivamogga Basavaraju, Surendra Halasuru Jayaram. Morphometric Analysis of Karadya Micro Watershed: A Case Study of Mandya District. American Journal of RemoteSensing. Vol. 6, No. 1, 2018, pp. 15-22. doi: $10.11648 /$ j.ajrs.20180601.13

Received: January 16, 2018; Accepted: February 5, 2018; Published: March 14, 2018

\begin{abstract}
Water is one of the essential natural resource for the very survival of life becoming a scarce commodity. It is very important to manage this very essential natural resource at micro watershed level for achieving sustainable development. The morphometric analysis plays a vital role in understanding the hydro-geological behavior of drainage basin. Remote sensing and Geographical Information System (GIS) techniques are proven efficient tool for morphometric analysis of a drainage basin throughout the world. Hence, an attempt has been made in this paper to study morphometric parameters of Karadya micro watershed using Geographical information system(GIS) approach. The study reveals that the terrain exhibits dendritic type drainage pattern with highest stream order being third order. The drainage density of watershed is $2.65 \mathrm{~km}-1$. The mean bifurcation ratio of the entire basin is 6.73 indicating that the drainage pattern is not much influenced by geological structures. Relief ratio indicates that the discharge capability of these watersheds is very high and the ground water potential is low. Further, the study reveals that GIS techniques proved to be a competent tool in morphometric analysis helps in planning and management of watershed.
\end{abstract}

Keywords: GIS, Micro Watershed, Morphmetric Parameters, Remote Sensing

\section{Introduction}

Water is one of the essential natural resource for the very survival of life on the planet earth. This essential natural resource is becoming a scarce commodity due to various reasons needs to be conserved. Conservation of available natural resources through demarcation of potential zones at micro watershed level are primary necessitate for achieving sustainable development. A watershed is an ideal unit calling for multidisciplinary approach to the resource management for insuring continuous benefits on sustainable basis.

Morphometry is the measurement and mathematical analysis of the configuration of the earth's surface, shape and dimension of its landforms [3]. Morphometric analysis of a watershed provides a quantitative description of the drainage system, which is an important aspect of the characterization of watersheds [32]. An understanding of the hydrological behavior of a watershed is important for effective planning and management of land and water resources development.

Morphometric analysis of a watershed involves the measurement of linear features, aerial aspects and gradient of channel network and contributing ground slope of the drainage basin [20]. To understand the evolution and behavior of drainage patterns, several methods have been developed like traditional methods such as field observations and topographic maps and advanced methods like remote sensing and GIS [14, 28]. In traditional methods, it is difficult to examine all drainage networks from field observations due to their extent throughout rough terrain and or vast areas. Remote Sensing coupled with GIS 
technique as emerged as powerful tool in the recent years in analyzing the drainage morphometry throughout the world. These techniques have been immense utility for the analysis of morphometric parameters to arrive cost effective plans for conservation and development measures for watersheds at micro level. Many soft computing techniques were employed to estimate the water consumption under different climatic conditions [7, 8, 9, and 10]

In India, some of the studies on morphometric analysis using remote sensing and GIS technique were carried out by $[1,2,11,12,13,18,19,20,21,23,24,30] \&$ others have revealed that the results obtained by GIS and remote sensing technique were reliable and accurate and aid in watershed management. Hence, an attempt has been made to study the morphometric analysis of KARADYA micro watershed using Geographical Information System (GIS) techniques for water resource planning, conservation and management.

\section{Study Area}

The Karadya watershed is situated in Mandya district, Karnataka, India and geographically is located between $76^{\circ} 37^{\prime} 30^{\prime \prime}$ and $76^{\circ} 45^{\prime} \mathrm{E}$ longitude and $12^{\circ} 45^{\prime}$ and $12^{\circ} 37^{\prime} 30^{\prime \prime} \mathrm{N}$ latitude. The study covers an area of $23.95 \mathrm{~km}^{2}$ having a maximum length of $7.34 \mathrm{~km}$ and width of $5.04 \mathrm{~km}$. The study area attains maximum elevation of $1065.000 \mathrm{~m}$ and a minimum of $848.000 \mathrm{~m}$. It has a typical sub tropical climate with hot dry summers and cool dry winters. Temperature varies between the minimum of $15^{\circ} \mathrm{C}$ during December or January months to the maximum of $35^{\circ} \mathrm{C}$ in May or June. The rainfall in the study area is highly erratic varying between $400 \mathrm{~mm}$ to $1200 \mathrm{~mm}$.

\section{KHARADYA MILLI WATERSHED}
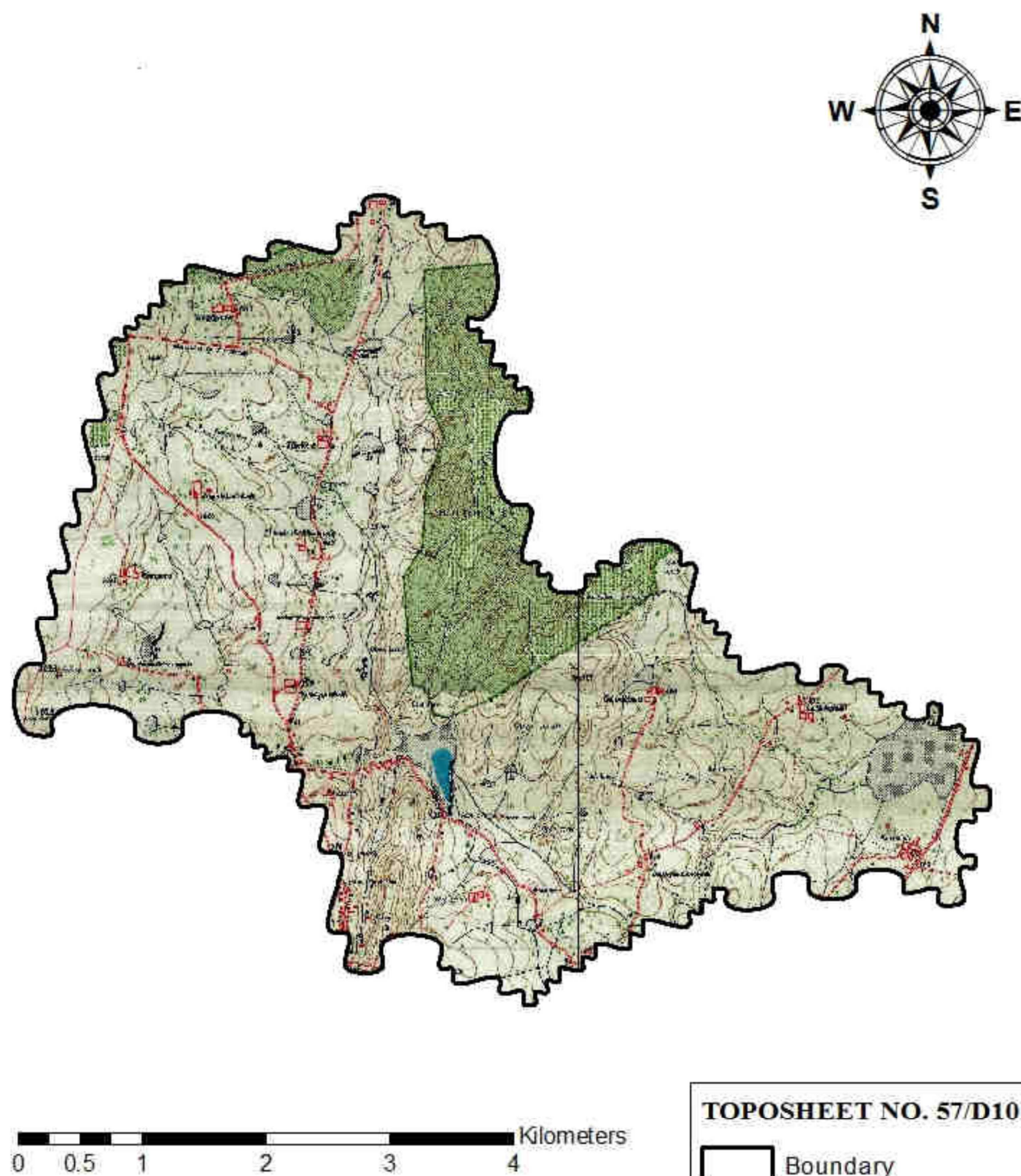

TOPOSHEET NO. 57/D10

Boundary

Figure 1. Location map of Kharadya microwatershed. 


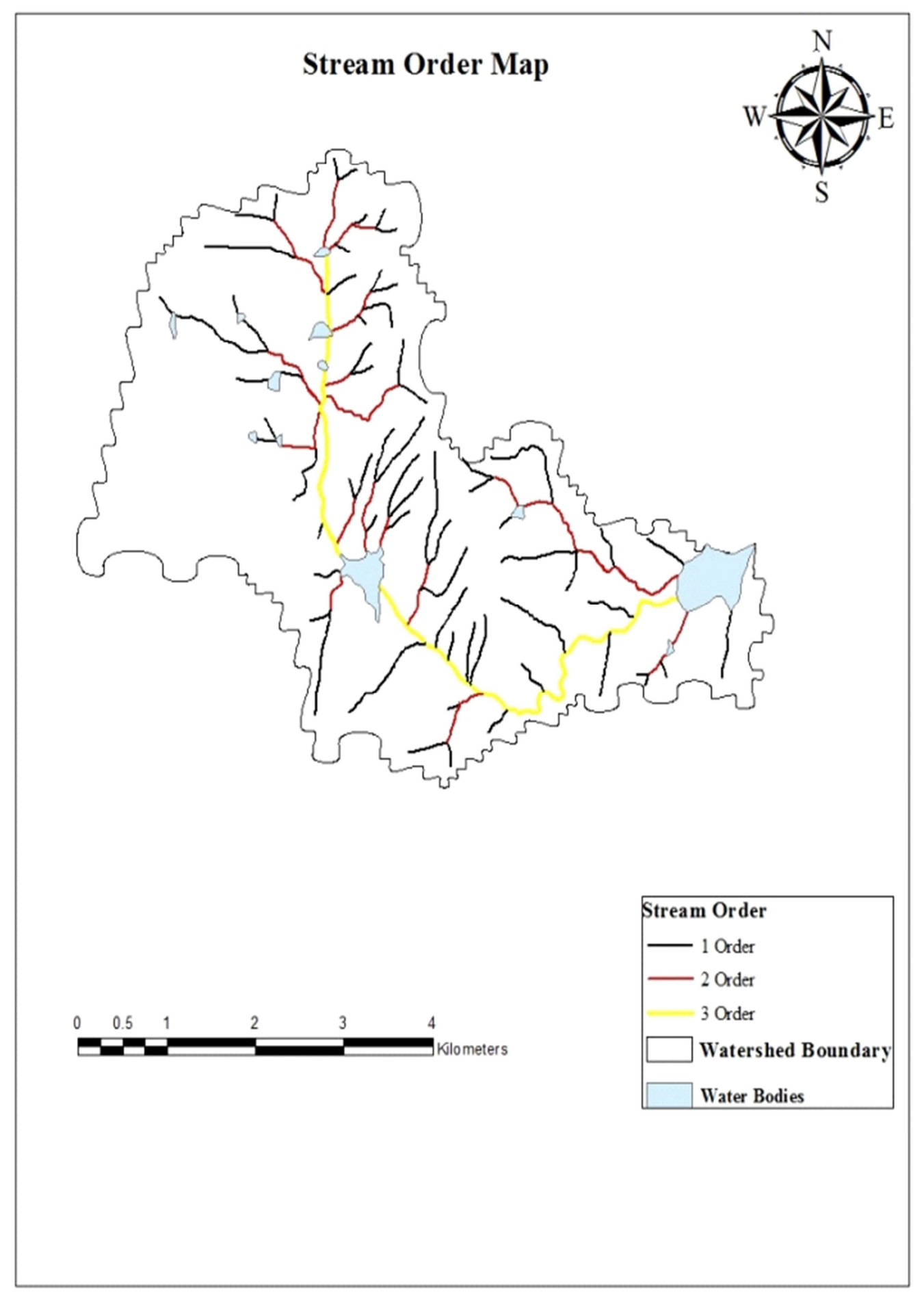

Figure 2. Stream orders Map of the Karadya micro watershed.

\section{Methodology}

In this study, Topographic map on a scale of 1:25000 prepared by Survey of India (SOI) bearing number $57 \mathrm{D} / 10$ was used. To delineate the water shed boundary and drainage pattern the top sheet was Geo-referenced and digitized. The Landsat TM satellite images used to get the drainage pattern of different orders of the basin. Drainage basin morphometric parameters and stream order characteristics of the area were extracted from the digitized data using the Strahler's method of stream ordering and also DEM and Slope maps were prepared with the help of Remote Sensing and GIS techniques (ArcGIS). In the present study the morphometric parameters such as linear, area land relief aspects of the watershed have been computed using the formulae developed by different researchers as presented in Table 1. 
Table 1. Linear Relief and Areal Morphometric Parameters.

\begin{tabular}{llll}
\hline Sl. No. & Parameters & Formulae & References \\
\hline 1 & Stream Order(U) & Hierarchical rank & Strahler(1964) \\
2 & Stream Length(Lu) & Length of the stream & Horton(1945) \\
3 & Mean Stream Length (Lsm) & $\mathrm{Lsm}=\mathrm{Lu} / \mathrm{Nu}$ & Strahler(1964) \\
4 & Stream Length Ratio(RL) & $\mathrm{RL}=\mathrm{Lu} / \mathrm{Lu}-1$ & Horton(1945) \\
5 & Bifurcation Ratio(Rb) & $\mathrm{Rb}=\mathrm{Nu} / \mathrm{Nu}+1$ & Schumm(1956) \\
6 & Mean Bifurcation Ratio(Rbm) & $\mathrm{Rbm}=$ average of bifurcation ratio so fall order & Strahler $(1957)$ \\
7 & Drainage density(Dd) & $\mathrm{Dd}=\mathrm{Lu} / \mathrm{A}$ & Horton $(1945)$ \\
8 & Drainage texture(T) & $\mathrm{T}=\mathrm{DdxFs}$ & Smith(1950) \\
9 & Stream Frequency(Fs) & $\mathrm{Fs}=\mathrm{Nu} / \mathrm{A}$ & Horton $(1945)$ \\
10 & Elongation ratio(Re) & $\mathrm{Re}=\mathrm{D} / \mathrm{L}=1.128 \mathrm{~A}^{1 / 2} / \mathrm{L}$ & Schumm $(1956)$ \\
11 & Circularity ratio(Rc) & $\mathrm{Rc}=4 \pi \mathrm{A} / \mathrm{P}^{2}$ & Strahler1964 \\
12 & Form factor(Ff) & $\mathrm{Ff}=\mathrm{A} / \mathrm{L}^{2}$ & Horton $(1945)$ \\
13 & Length of over land flow $(\mathrm{Lg})$ & $\mathrm{Lg}=1 / \mathrm{D}^{*} 2$ & Horton $(1945)$ \\
14 & Relief & $\mathrm{R}=\mathrm{H}-\mathrm{h}$ & Hadley and Schumm $(1961)$ \\
15 & Relief Ratio & $\mathrm{Rr}=\mathrm{R} / \mathrm{L}$ & Schumm $(1963)$ \\
\hline
\end{tabular}

\section{Results and Discussion}

\subsection{Morphometric Parameters}

The morphometric analysis of the drainage basin plays an important role in understanding the geo-hydrological behavior of drainage basin and expresses the prevailing climate, geology, geomorphology, structural antecedents of the catchment. The values of various basin characteristics required for calculating morphometric parameters are discussed briefly. The morphometric parameters were analyzed and divided in three categories:(1)linear aspect (2) area land (3) relief aspect

\subsubsection{Linear Aspects}

Linear aspects of the basins are closely linked with the channel patterns of the drainage network where in the topological characteristics of the stream segments in terms of open links of the network system are analyzed. The morphometric investigations of linear parameters of the basin includes Number of Stream (Nu), Stream Length(Lu), Mean Stream Length(Lsm), Stream Length Ratio(Rl), Bifurcation Ratio(Rb) and Mean Bifurcation Ratio(Rbm) of the watershed. The results of the linear parameters are presented in Table 2.

Table 2. Results of Linear morphmetric parameters.

\begin{tabular}{|c|c|c|c|c|c|c|c|c|c|}
\hline SI. No & $\begin{array}{l}\text { Stream } \\
\text { order }\end{array}$ & $\begin{array}{l}\text { Number } \\
\text { of streams }\end{array}$ & $\begin{array}{l}\text { Stream } \\
\text { length(km) }\end{array}$ & $\begin{array}{l}\text { Mean Stream } \\
\text { length }\end{array}$ & $\begin{array}{l}\text { Stream length } \\
\text { ratio }\end{array}$ & $\begin{array}{l}\text { Bifurcation } \\
\text { ratio }\end{array}$ & $\begin{array}{l}\text { Mean } \\
\text { Bifurcation } \\
\text { ratio }\end{array}$ & $\begin{array}{l}\text { Drainage } \\
\text { Density } \\
\left(\mathrm{Km} / \mathbf{k m}^{2}\right)\end{array}$ & $\begin{array}{l}\text { Length of over } \\
\text { land flow }(\mathrm{Km})\end{array}$ \\
\hline 1 & 1 & 67 & 33.426 & 0.50 & - & - & & & \\
\hline 2 & 2 & 16 & 13.640 & 0.85 & 1.70 & 4.18 & 6.73 & 2.65 & 0.19 \\
\hline 3 & 3 & 1 & 8.040 & 8.04 & 9.458 & 16 & & & \\
\hline
\end{tabular}

\subsubsection{Stream Order}

The designation of stream order is the first step in morphometric analysis of a drainage basin. Herein, the number of streams gradually decreases with increase in stream order. According to [32], the1st order streams are those, which have no tributaries. The $2^{\text {nd }}$ order streams are those, which have tributaries only of $1^{\text {st }}$ order streams, where two $2^{\text {nd }}$ order channels join, a segment of $3^{\text {rd }}$ order is formed and soon. The variation in stream order is due to physiographic and structural condition of the region. As per Strahler's method study area is third order drainage basin is shown Figure 2.

\subsubsection{Stream Length}

Stream length is one of the most important hydrological features of the basin indicate the variation of surface runoff behaviors. Longer lengths of streams are generally indicative of flatter gradients. The stream length is higher for the first order and decreases as the stream order increases. The stream length has been computed based on the law proposed by Horton, with the help of GIS software. In the present work, results show that the total length of stream is more in case of first order stream sand decreases with the increase in the stream order as shown in Table 2. The overall length of 84 streams of water shed is $55.106 \mathrm{~km}$. The lengths of first order, second order and third order streams are $33.426 \mathrm{~km}, 13.64 \mathrm{~km}$ and $8.04 \mathrm{~km}$ respectively.

\subsubsection{Stream Number}

The order wise total number of stream segment is known as the stream number. Higher the stream number indicates lesser permeability and infiltration. It leads to inference that several stream usually upsurges in geometric progression as stream order increases. The results of study area reveal that the number of streams in the first-order is 67 and accounts for $79.76 \%$ of all segments. The number of streams in second-order is 16 and accounts for $19.04 \%$ while the number of streams in third order is only 1and account for $1.19 \%$. The results are shown in the Figure 3. As per Horton's [6] laws the stream number decreases in geometric progression as the stream order increases. 


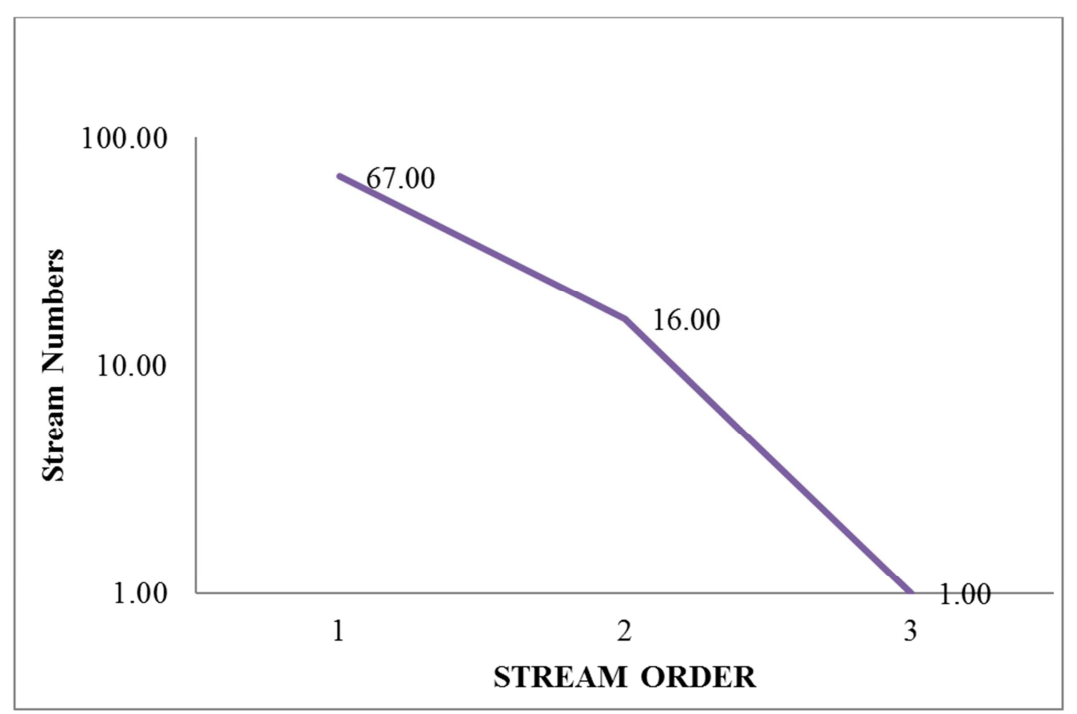

Figure 3. Stream order v/s Stream Number.

\subsubsection{Mean Stream Length}

Mean Stream length is a dimensional property revealing the characteristic size of components of a drainage network and its contributing watershed surfaces [32]. It's directly proportional to the size and topography of drainage basin. It is obtained by dividing the total length of stream of an order by total number of segments in the same order. The mean stream length of any given order is greater than that of lower order in all watersheds. The mean length of the study area is 0.50 for first order, 0.85 for second order and 8.04 for third order respectively.

\subsubsection{Stream Length Ratio}

Stream length ratio may be defined as the ratio of the mean length of the one order to the next lower order of stream segment. The mean stream length of the given order is higher than the previous order and lower than the next successive order. The stream length ratio has important relevance with surface flow and discharge and erosion stage of the basin. The stream length ratio of study area is 1.7 and 9.458 respectively. The increase in stream length ratio from lower to higher order shows that the study area has reached a mature geomorphic stage.

\subsubsection{Bifurcation Ratio}

Bifurcation ratio is closely related to the branching pattern of a drainage network. It is the ratio of the number of the stream segments of given order ' $\mathrm{Nu}$ ' to the number of streams in the next higher order $(\mathrm{Nu}+1)[25,6,25]$ considered the bifurcation ratio as an index of relief and dissection. The bifurcation ratio is dimension less property indicates the degree of integration prevailing between streams of various orders in drainage basin and generally ranges from 3.0 to 5.0. In the study bifurcation ratio varies from 4.19 to 16 and mean of bifurcation ratio for entire basin was 6.73 which is higher than the range of 3.0 to 5.0. The higher value of the mean bifurcation ratio indicates a high structural complexity and low permeability of the terrain [22].

\subsubsection{Length of Overland Flow}

It is the length of water over the ground before it gets concentrated into definite streams channels [6]. It is approximately equals to half of reciprocal of drainage density. This factor depends on the rock type, permeability, climatic regime, vegetation cover and relief as well as duration of erosion [25]. Higher the values of Length of overland flow lower will be the relief and vice versa. The value of length of overland flow in Karadya watershed is 0.19 may be under the influence of high structural disturbance, low permeability, steep to very steep slopes and high surface runoff.

\subsection{Drainage Pattern}

The drainage pattern reflects the influence of slope, lithology and structure of the watershed. The study of drainage pattern helps in identifying the stage in the cycle of erosion. The drainage pattern of the study area have been observed as mainly dendritic type(Figure3) which indicates the homogeneity in texture and lack of structural control.

\subsubsection{Areal Aspects}

Areal aspects of a watershed of given order is defined as the total area projected upon a horizontal plane contributing over land flow to the channel segment of the given order and includes all tributaries of lower order. Area and perimeter of a basin are the important parameters in quantitative geomorphology. The area of the basin is defined as the total area projected upon a horizontal plane. Perimeter is length of the boundary of the basin. Areal aspects of the drainage basin such as drainage density, drainage texture, stream frequency, form factor, circularity ratio, elongation ratio, shape factor, compactness coefficient were calculated and results are given in Table 3. 
Table 3. Result of Areal aspects of Karadya watershed.

\begin{tabular}{llll}
\hline Sl. No. & Watershed Parameters & Units & Values \\
\hline 1 & Watershed area & sq.km & 23.95 \\
2 & Perimeter of Watershed & $\mathrm{km}$ & 23.43 \\
3 & Maximum length of watershed & $\mathrm{km}$ & 7.34 \\
4 & Maximum width of watershed & $\mathrm{km}$ & 5.04 \\
5 & Drainage density & $\mathrm{km} / \mathrm{sq} \cdot \mathrm{km}$ & 2.65 \\
6 & Drainage texture & & 3.585 \\
7 & Stream frequency & $\mathrm{No} / \mathrm{sq} \cdot \mathrm{km}$ & 3.507 \\
8 & Elongation ratio & - & 1.81 \\
9 & Circularity ratio & - & 2.20 \\
10 & Form factor & - & 0.69 \\
11 & Constant Channel Maintenance & sq.km $/ \mathrm{km}$ & 0.38 \\
12 & Compact coefficient & & 1.45 \\
13 & WS factor & & 2.59 \\
14 & Stream Frequency & & 4.03 \\
\hline
\end{tabular}

\subsubsection{Drainage Area}

The fundamental unit of virtually all watershed and fluvial investigations is the drainage area. An individual drainage basin is a finite area whose runoff is channeled through a single outlet. It is enclosed within the boundary of the watershed divide. A drainage divide is simply a line on either side of which water flows to different streams. Drainage area measures the average drainage area of streams in each order; it increases exponentially with increasing order. The drainage area of the study area was found to be 23.95 sq. $\mathrm{km}$.

\subsubsection{Drainage Density}

It is a measure of the total length of the stream segment of all order per unit area. The drainage density indirectly indicates the ground water potential of an area, due to its relation with surface runoff and permeability. Slope gradient and relative relief are the main morphological factor of drainage density. Higher the range of drainage density faster the runoff will be and it also suggests that the value vary between 0.55 and $2.09 \mathrm{~km} / \mathrm{km}^{2}$ in a humid region with an average of $1.03 \mathrm{~km} / \mathrm{km}^{2}$ [22]. Low drainage density generally result in the area of highly resistant or permeable sub soil material and high drainage density is the resultant of weak or impermeable sub surface material [26, 27]. Low drainage density leads to coarse drainage texture while high drainage density leads to fine drainage texture. The drainage density of the study area is $2.65 \mathrm{~km} / \mathrm{km}^{2}$ which indicate that the basin has moderate permeable drainage.

\subsubsection{Drainage Texture}

It is the total number of stream segment so fall orders per perimeter of the basin (Horton1945). The drainage texture depends upon a number of natural factors such as rainfall, vegetation, climate, rock and soil type, infiltration capacity, relief and stage of development. It is important to understand geomorphology which means that the relative spacing of drainage lines. The drainage texture has been classified into five different texture such as very coarse $(<2)$, coarse $(2$ to 4$)$, moderate (4 to 6), fine (6 to 8 ) and very fine $(>8)$ (Smith1950). The drainage texture of study area is 3.585 and can be categorized as moderate in nature.

\subsubsection{Stream Frequency}

The stream frequency or channel frequency is the total number of stream segments of all order per unit area [5]. Stream frequency reflects the texture of the drainage density. The stream frequency value of the study area is 3.507 exhibits a positive correlation with drainage density valve of the area indicating increase in stream population with increase in drainage density.

\subsubsection{Circularity Ratio}

The circularity ratio is the ratio of the area of the basin to the area of a circle having the same circumference as the perimeter of the basin [17]. Circularity ratio is dimensionless and expresses the degree of circularity of the basin depends on stream flow in the watershed. It is influenced by the length and frequency of streams, geological structures, land use/land cover, climate and slope of the basin. It is a significant ratio that indicates the dendritic stage of a watershed. Low, medium and high values of circularity ratio indicate the young, mature, and old stages of the life cycle of the tributary watershed. Circularity ratio value for the study area was obtained as 2.20 and it indicated the basin has maturity stage of topography.

\subsubsection{Form Factor}

Form factor is a dimensionless ratio of watershed area to the square of the length of the watershed [5]. This factor indicates the flow intensity of a basin of a defined area. The form factor values vary from 0 (in highly elongated shape) to1 (in perfect circular shape). Value greater than 0.78 indicated the perfectly circular basin, smaller values suggest the elongated form of basin. The value of form factor for the study is 0.69 indicating that basin is more or less circular basin.

\subsubsection{Elongation Ratio}

The elongation ratio is the ratio between the diameter of the circle of the same area as the drainage basin and the maximum length of the basin [25]. It is a very significant index in the analysis of basin shape which helps to give an idea about the hydrological character of a drainage basin. The values elongation ratio are grouped into three class namely circular ( $>0.9)$, Oval (0.9-0.8), and less elongated (0.8-0.7) and elongated $(<0.7)$. A circular basin is more efficient in the discharge of runoff than an elongated basin [26, 27]. The elongation ratio of the study area is 1.81 which indicates that the water shed is circular in nature more efficient in the discharge of runoff.

\subsection{Constant of Channel Maintenance}

The constant of channel maintenance is the inverse of drainage density. It indicates the relative size of land form units in a drainage basin and has a specific genetic connotation[31]. The value of the constant of channel maintenance for the study area is $0.38 \mathrm{Sq} . \mathrm{km} / \mathrm{km}$ is under the influence of high structural disturbance, low permeability, steep to very steep slopes and high surface runoff. 


\subsubsection{Relief Aspects}

Relief aspects of drainage basin relate to the three dimensional features of the basin involving area, volume and altitude of vertical dimension of landforms where in different morphometric methods are used to analyze terrain characteristics. Relief aspects include relief, relief ratio and ruggedness numbers indicate the erosion potential of the processes operating within a drainage basin. The results of a real aspect of Karadya watershed are given inTable4.

Table 4. Result of Areal aspects of Karadya watershed.

\begin{tabular}{llll}
\hline Sl. No. & Watershed Parameters & Units & Valves \\
\hline 1 & Highest elevation of watershed & $\mathrm{m}$ & 1065 \\
2 & Lowest elevation of watershed & $\mathrm{m}$ & 848 \\
3 & Drainage density & $\mathrm{km} / \mathrm{sq} \cdot \mathrm{km}$ & 2.65 \\
4 & Overall relief of watershed & $\mathrm{m}$ & 217 \\
5 & Relief ratio & - & 29.57 \\
6 & Relative Relief ratio & - & 9.26 \\
7 & Ruggedness number & - & 0.575 \\
\hline
\end{tabular}

\subsubsection{Watershed Relief}

Water shed relief is the difference in elevation between the lowest and the highest point of the watershed. Relief is an important factor in understanding the denudational characteristics of the basin and plays a significant role in land forms development, drainage development, surface and subsurface water flow, permeability and erosional properties of the terrain [15]. The high relief value indicates high gravity of water flow, low permeable and high runoff conditions. The difference in elevation between the remotest point and discharge point is obtained from the available contour map. The highest elevation of watershed was $1065 \mathrm{~m}$ above mean sea level and the lowest relief was $848 \mathrm{~m}$ above mean sea level. The overall relief calculated for the watershed was $217 \mathrm{~m}$.

\subsubsection{Relief Ratio (Rh)}

The ratio of basin relief to basin length (horizontal distance along the longest dimension of the basin parallel to the principal drainage line) is Relief Ratio(Rh) [25]. It is used to measure the overall steepness of a river basin and is an indicator of intensity of erosion processes operating on the slopes of the basin. For the present study, relief ratio is 0.002957 . The high value of relief ratio is characteristics of hilly region.

\subsubsection{Relative Relief Ratio (Rbh)}

It is an important morphometric variable used for the overall assessment of morphological characteristics of any topography [4]. [16] suggested to calculate relative relief by dividing relief ratio by basin perimeter and classified into three categories viz.(i)low relative relief is lies between 0 to $100 \mathrm{~m}$, (ii)moderately relative relief is lies between 100 to $300 \mathrm{~m}$ and (iii) high relative relief is above $300 \mathrm{~m}$. From the study the valve of the relative relief ratio of the study area was 9.26 indicating the study area is a low relative relief.

\subsubsection{Ruggedness Numbers (HD)}

[31] Defined the ruggedness number as the product of the basin relief and the drainage density where both parameters are in the same unit and usefully combines slope steepness with its length. The valve of the ruggedness number calculated for the Karadya watershed is 0.575 . The low ruggedness value of watershed implies that area is less prone to soil erosion and have intrinsic structural complexity in association with relief and drainage density.

\section{Conclusions}

Quantitative analysis of morphometric parameters of the water shed is found to be very useful in the drainage basin evaluation, water conservation and natural resource management at micro level. Morphometric analysis of the study area is characterized by dendritic type drainage basin. Lower order streams dominate the basin with highest stream order being third order. Higher mean bifurcation ratio of the study area indicates a strong structural control on the drainage pattern of watershed. The value of form factor and circulator ratio and elongation ratio indicates that Karardya water shed is circular in shape having high runoff with low ground water potential. Further, the study concludes that ASTER(DEM) data coupled with GIS technique is a competent tool to analyze the morphometric parameters for water resource management at micro level of any terrain by planners and decision makers to develop strategy for sustainable watershed development programs.

\section{References}

[1] Arun, (2005), "A rule base physio graphic characterization of a drought prone watershed applying remote Sensing and GIS", Journal of the Indian Society of Remote Sensing, 33, No.2, 2005p. 189-201.

[2] Chopra, R., Dhiman, R., and Sharma, P. K (2005),"Morphometric analysis of sub watersheds in Gurdaspur District, Punjab using Remote Sensing and GIS techniques", Journal of Indian Society of RemoteSensing, 33(4), pp531-539.

[3] ClarkeJ. I (1996)“ Morphometry from maps, in Dury G. H (Ed), essay in geomorphology”. American Elsevier Publ., Co., NewYork, pp 235-274.

[4] Gayen S, Bhunia GS, Shi PK (2013)"Morphometric analysis of Kangshabati-Darkeswar Interfluves area in West Bengal, India using ASTER DEM and GIS techniques", GeolGeosci 2(4):1-10.

[5] Horton, R. E.,(1932),"Drainage Basin Characteristics, Transactions", American Geophysical Union, 13, pp. 350-361.

[6] Horton, R. E.,(1945),“Erosional Development of Streams and their Drainage Basins Hydrophysical approach to quantitative morphology "Geological Society of America Bulletin, 56(3), pp. 275-370.

[7] H J Surendra., Darshan H T., Gagan B R., LikithRaj., Shreyas Gowda KJ(2017). "Estimation of Evapotranspiration for Onion crop in semi-arid region: Experimental Field setup using Lysimeter". Science PG publication, DOI:10.11648/j.urp.20180301.11 ISSN:25751689(Print);ISSN:2575-1697(Online), 2018;Vol3, No:1, pp. 1-5. 
[8] H. J. Surendra, Deka P C and Kavya B M (2017), "Improved Framework for modeling Municipal Residential Water Consumption Estimation using Wavelet-Mamdani Fuzzy approach". International Journal of Advance research in science and engineering, Vol. no6, Issue. No8, ISSN(O):23198354, ISSN(P):2319-8346 August 2017.

[9] H. J. Surendra, Paresh Chandra Deka (2012),"Effects of Statistical Properties of Data Set in Predicting Performance of Various Artificial Intelligence Techniques for Urban Water Consumption Time Series". International Journal of Civil Engineering and Technology, volume3, Issue-2, JulyDecember (2012), PP-426-436.

[10] H. J. Ningaraju, Ganesh Kumar S. B and H. J. Surendra (2016), "Estimation of Runoff Using SCS-CN and GIS method in un-gauged watershed: A case study of Kharadya mill watershed, India". International Journal of Advanced Engineering Research and Science ISSN:2349-6495.

[11] Kumar, R., Kumar, S., Lohni, A. K., Neema, R. K. and Singh, A. D.,(2000) "Evaluation of geo morphological characteristics of a catchment using GIS", GIS India, 9(3):13-17.

[12] Kumar, R., Lohani, A. K., Kumar, S., Chatterjee, C. and Nema, R. K., (2001), "GIS based morphometric analysis of Ajay river basin upto Sarath gauging site of South Bihar", J. App. Hydro., 15(4):45-54.

[13] Kumar, (2010), "Micro watershed characterization and prioritization using Geomatics technology for natural resources management" International Journal of Geomatics and Geoscience, Volume 1, No 4, 2011, pp789-802.

[14] Macka, Z.,(2001), "Determination of texture of topography from large scale contourmaps". Geografski Vestnik, 73(2):5362 .

[15] Magesh N S, Chandrasekar N, Soundranayagam J P (2011) "Morphometric evaluation of Papanasam and Manimuthar watersheds, parts of Western Ghats, Tirunelveli district, Tamil Nadu, India: a GIS approach", Environ EarthSci 64(2):373381 .

[16] Melton M A(1958) "Geometric properties of mature drainage system and their representation in their E4 phase space". Journal of Geology 66: pp 35-36.

[17] Miller V C (1953) "A quantitative geomorphologic study of drainage basin characteristics in the clinch mountain area, Virginia and Tennesse Project NR 389-042", Technical Report 3, Columbia University, Department of Geology, ONR Geography branch, New york.

[18] Mishra, (2010) "Morphometric analysis and prioritization of sub-watershed using GIS \& Remote Sensing techniques: a case study of Odisha, India", International Journal of Geomatics and Geosciences, 1(4), pp: 501-501.

[19] Nag S K (1998) "Morphometric analysis using remote sensing techniques in the Chaka Sub-basin, Purulia District, West Bengal", Journal of Indian Society of Remote Sensing, 26 (1\&2), pp69-76.
[20] Nautiyal MD (1994) "Morphometric analysis of adrainage basin, district Dehradun, UttarPradesh", Jindian Soc Remote Sens 22(4): 251-261.

[21] Pal. B,(2012)"Morphometric and hydrological analysis and mapping for Watut watershed using Remote Sensing and GIS Techniques", International Journal of Advances in Engineering and Technology, Jan2012, pp357-368.

[22] Pankaj A, Kumar P (2009) "GIS-based morphometric analysis of five major sub-watersheds of Song River, Dehradun District, Uttarakhand with special reference to land slide incidences" Journal of the Indian Society of Remote Sensing, Volume 37, Issue1, pp157-166.

[23] Rao K L (2010) "Morphometric Analysis of Gostani River Basin in Andhra Pradesh State, India Using Spatial Information Technical", International Journal of Geomatics and Geosciences, 1(2), pp 179-187.

[24] Rekha,(2011) "Morphometric Analysis and Micro-watershed Prioritization of Peruvanthanam Sub watershed, the Manimala River Basin, Kerala, South India” Environmental Research, Engineering and Management, 3(57), pp 6-14.

[25] Schumn SA (1956) "Evolution of drainage systems and slopes in badlands at Perth Amboy, New Jersey". Geological Society of American Bulletin67:597-646.

[26] Singh. V, (2011), "Linear Aspect of the Maingra River Basin Morphometry, District Gwalior, Madhya Pradesh, India", International Journal of Science and Advanced Technology, 1(5) pp212-222.

[27] Singh, S., and Singh, M. C.(1997), "Morphometric analysis of Kanhar river basin", National Geographical Journal of India, 43(1), pp31-43.

[28] Sreedevi, P. D., Owais, S., Khan, H. H. and Ahmed, S., (2009), "Morphometric Analysis of a Watershed of South India Using SRTM Data and GIS". J. Geol. Soc. India, 73: $543-552$.

[29] Srinivasa, V. S., Govindaonah, S. and Home Gowda, H (2004), "Morphometric analysis of sub watersheds in the Pawagada area of Tumkur district South India using Remote Sensing and GIS Techniques", J. Indian Soc. Remote Sensing, 32(4) pp 351362.

[30] Srivastava, V. K.(1997) "Study of drainage pattern of Jharia coal field (Bihar), India, through Remote Sensing Technology". J. Indian Soc. RemoteSensing, 25(1):41-46.

[31] Strahler A N (1957)" Quantitative Analysis of Watershed Geomorphology" Transactions American Geophysical Union 38(6), 913-920.

[32] Strahler A N, Chow V T(1964) "Quantitative geomorphology of drainage basins and channel network, "Hand book of Applied Hydrology, McGraw Hill Book Company, New York, USA. 